\title{
АЛГОРИТМ РЕАБІЛІТАЦІЇ ВІЙСЬКОВОСЛУЖБОВЦІВ З АМПУТАЦІЄЮ КІНЦІВОК НА ОСНОВІ МУЛЬТИПРОФЕСІЙНОГО ТА ІНДИВІДУАЛЬНОГО ПІДХОДУ
}

\author{
А.А. Беспаленкоㄹ, О.І. Щеглюк ${ }^{1}$, А.Ю. Кіх ${ }^{1}$, О.А. Бур'янов², О.М. Волянський ${ }^{1}$, \\ В.В. Корченок ${ }^{1}$ М.М. Михайловська ${ }^{1}$
}

\author{
${ }_{1}^{1}$ Військово-медичний клінічний лікувально-реабілітаційний центр, м. Ірпінь \\ ${ }^{2}$ Національний медичний університет імені О.О. Богомольця, м Київ
}

Вступ. За даними літератури, серед учасників АТО, ООС переважають поранення кінцівок - 62,5\%. Частота ампутації зберігається відносно високою, часто поєднується з іншими травмами м'язовоскелетної системи та потребує індивідуального та мультипрофесійного (МП) підходу.

Мета дослідження: провести аналіз структури ампутацій в учасників АТО ООС; створити алгоритм реабілітації військовослужбовців з ампутаціями, враховуючи індивідуальний та МП підхід.

Матеріали та методи. Проведено аналіз результатів лікування 51 пацієнта з ампутацією з числа учасників АТО, ООС, які були госпіталізовані у відділення реабілітації пацієнтів з ампутованими кінцівками Військово-медичного клінічного лікувально-реабілітаційного центру в період з 26.12 .2016 по 01.08.2019. Середній вік на момент поранення складав - 33 роки (від 18 до 54). Розподіл за статтю: чоловіки - 98,1\% (n=50), жінки - 1,9\% (n=1).

Результати. Відсутність однієї кінцівки внаслідок ампутації спостерігалася у 84,3\% (n=43), подвійна ампутація - у 13,7\% (n=7), потрійна - у 2,0\% (n=1). Основною причиною ампутації були мінновибухові поранення - 78,4\% (n=40). Найчастіше ампутація кінцівок поєднувалася з акубаротравмою - 47\% $(n=24)$ та закритою черепно-мозковою травмою - 41,2\% (n=21), порушенням адаптації та депресивними розладами - 56,8\% (n=29). У 31\% (n=16) ампутація поєднувалася з переломами трубчастих кісток інших кінцівок. Всі ці обставини суттєво впливали на перебіг реабілітації. Враховуючи вище зазначені обставини, було запропоновано алгоритм реабілітації пацієнтів з травматичною ампутацією в періопераційний період, період підготовки до протезування, протезування та віддалений період відповідно до індивідуальної програми реабілітації (IПР).

Висновки. Враховуючи особливості сучасної травми, а саме часту асоціацію ампутації з іншими м'язово-скелетними травмами, травмами внутрішніх органів, психологічними розладами, алгоритм ведення пацієнтів з ампутацією повинен включати: комплексне лікування з диференційованим індивідуальним підходом з застосування сучасних технологій, ранній початок реабілітації на основі МП підходу та згідно ІПР.

Ключові слова: ампутація, мультипрофесійний підхід, протезування, реабілітація.

Вступ. За даними літератури, втрата кінцівки внаслідок бойової травми, займає одне з провідних місць серед причин ампутації у більшості країн світу. За даними Центру травми кінцівок та ампутацій США, за період з 2001 по 2017 рр. 1718 військовослужбовців мали щонайменше одну ампутацію кінцівок (без урахування ампутації пальців) $[8,15]$. При цьому близько $31 \%$ військовослужбовців мали дві та більше ампутацій. Основною причиною втрати кінцівок була вибухова травма - 73\%. У Великобританії загальна кількість військовослужбовців 3 ампутаціями за період 2013-2018 рр. становила 176, 3 них 113 внаслідок бойової травми $[5,8,16]$. Актуальність даної проблеми в Україні значно зросла з 2014 року, що пов'язано з початком бойових дій внаслідок російської агресії на Сході. Згідно досліджень, в загальній структурі поранення учасників АТО, ООС переважають поранення кінцівок - 62,5\% [12]. При цьому основною причиною, що призводять до втрати кінцівок $\epsilon$ ураження високоенергетичною зброєю. Так, 74,8\% ампутацій спричинені мінно-вибуховою травмою [12]. Варто зазначити, що незважаючи на значне покращення процесу організації надання медичної допомоги, рівень ампутацій залишається відносно високий - близько 4\% (168) станом на кінець 2016 року [9]. Такі умови зумовлюють потребу у підвищенні якості надання медичної допомоги на етапах лікування та реабілітації, створення чітких алгоритмів 3 урахуванням досвіду передових країн НАТО. Так, у США з метою розширення медичного обслуговування та лікування пацієнтів-ветеранів із ризиком первинної або вторинної втрати кінцівки було розроблено програму загальної профілактики ампутації у ветеранів, направлену на запобігання втрати кінцівки або її відтермінування [14]. Крім цього, Міністерством у справах 
ветеранів США було затверджено клінічні настанови щодо підходів з надання медичної допомоги після ампутації із залученням мультипрофесійної групи. Відповідно до цих настанов, надання медичної допомоги та навчання пацієнтів з ампутацією комплексне і потребує залучення фахівців різних медичних, хірургічних та реабілітаційних спеціальностей. Окрім пацієнта, членами команди медичної реабілітації можуть бути особи, які займаються обслуговуванням пацієнта, хірург, фізіотерапевт, спеціаліст із лікувальної фізкультури, ерготерапевт, спеціаліст із рекреаційної терапії, протезист, медична сестра, соціальний працівник, психіатр, консультант з аналогічним статусом та координатор медичних послуг [14, $15,17]$. Теми щодо яких лікарі повинні надавати чіткі рекомендації та інформацію: хірургічні втручання, довжина кукси, рівень ампутації, програми реабілітації, методи протезування та можливі результати з реальними цілями реабілітації $[2,3]$. На основі цих даних пацієнти можуть приймати зважені рішення щодо надання їм медичної допомоги. На кожному з етапів реабілітації проводиться моніторинг функціональних можливостей, контроль болю, цілісності шкірних покривів, маси тіла, наявність супутніх станів (наприклад, біль у нижній частині спини, біль у контралатеральній кінцівці), наявність недоліків в користуванні протезом, визначається потреба у відпустці та відпочинку, ступінь психологічної адаптації до ампутації $[13,18]$. На жаль, в Україні чіткої програми щодо запобігання ампутації, як і алгоритму реабілітації таких пацієнтів поки не існує, що часто призводить до помилок та ускладнень, яких можна було би запобігти. Даний алгоритм має враховувати як досвід країн НАТО, так i особливості умов організації та забезпечення надання медичної допомоги в Збройних Силах України.

Мета дослідження. Провести аналіз структури ампутацій в учасників АTO, OОС, дослідити особливості реабілітації та лікування пацієнтів з ампутацією внаслідок бойової травми, запропонувати алгоритм реабілітації з урахуванням індивідуального та МП підходу.

Матеріали та методи дослідження. Проведено аналіз результатів лікування 51 пацієнта з ампутацією з числа учасників ATO, OОC, які були госпіталізовані у відділення реабілітації пацієнтів з ампутованими кінцівками Військово-медичного клінічного центру професійної патології ЗСУ в період 3 26.12.2016 по 01.08.2019. Середній вік на момент поранення складав - 33 роки (від 18 до 54). Розподіл за статтю: чоловіки - 98,1\% (n=50), жінки - 1,9\% (n=1). За допомогою статистичних методів проведено аналіз структури ампутації відповідно до причини, локалізації, кількості ампутованих кінцівок, наявності ускладнень та супутніх станів, тощо. На основі аналізу досвіду країн НАТО, власного досвіду та враховуючи сучасні умови організації надання медичної допомоги в ЗСУ, запропоновано підхід до реабілітації пацієнтів з ампутованими кінцівками внаслідок бойової травми.

Результати дослідження. 3 метою досягнення максимального степеню функціональної активності пацієнта 3 ампутацією, алгоритм лікування та реабілітації повинен бути комплексним, враховувати характер травми, супутню патологію та травми, можливі ускладнення, морально-психологічний стан, сімейно-побутові обставини, тощо.

Результат дослідження показав, що у 78,4\% (n=40) причиною ампутації була мінновибухова травма, у 11,7\% (n=6) - вибухове поранення, у 5,9\% (3) - вогнепальне поранення, у $2 \%(\mathrm{n}=1)$ - осколкове, у 2\% (n=1) - як наслідок остеомієліту (рис 1). Така структура поранень схожа з країнами НАТО. Так, у США, як загадувалося вище, вибухові та мінно-вибухові поранення складають 73\% та $€$ головною причиною ампутації. Цю особливість варто враховувати при ампутації та оцінці життєздатності тканин, оскільки зона ураження тканин як правило є значно більшою, ніж видиме пошкодження. Крім того, мінно-вибухове поранення часто $€$ фактором ризику формування гетеротопічних осифікатів, що ускладнює та подовжує процес реабілітації.

Залежно від кількості ампутованих кінцівок: одна кінцівка - 84,3\% (n=43), дві кінцівки 13,7\% (n=7), три кінцівки (дві нижні та 1 верхня) - 2\% (n=1). У 90,2\% (n=32) пацієнтів було виконана ампутація нижніх кінцівок, у 9,8\% (n=5) - ампутація верхніх кінцівок. При цьому, ампутація нижніх кінцівок нижче рівня колінного суглобу склала переважну частку - 69\%, вище колінного суглоба - 31\%. У структурі верхньої кінцівки переважали ампутації на рівні нижньої третини передпліччя - 60\%. 
Варто зазначити, що у 31\% (n=16) спостерігалося поєднання ампутації та переломів трубчастих кісток інших кінцівок. Для максимально швидкої мобілізації таких пацієнтів важливим моментом є своєчасна заміна методу фіксації перелому та паралельне проведення протезування, що в свою чергу ще раз підтверджує необхідність індивідуального та МП підходу.

Серед супутньої патології найчастіше виявлялися акубаротравма - 47\% (n=24), закрита черепно-мозкова травма - 42,2\% (n=21), травми внутрішніх органів - 13,7\% (n=7), травматичні ураження очей - $15,6 \%(\mathrm{n}=8)$ (рис 2). Наявність супутніх травм та захворювань $\epsilon$ важливими факторами, що впливають на прогноз реабілітації. Так, наявність супутньої травми та/або захворювання, пов'язані 3 гіршими результатами після ампутації $[7,11]$. Крім того, частими супутніми розладами були порушення адаптації та депресивні розлади 56,8\% (n=29). Саме тому необхідно проводити періодичні оцінювання психічного статусу та психосоціальної функції (зокрема релігійна віра та механізми подолання життєвих труднощів).

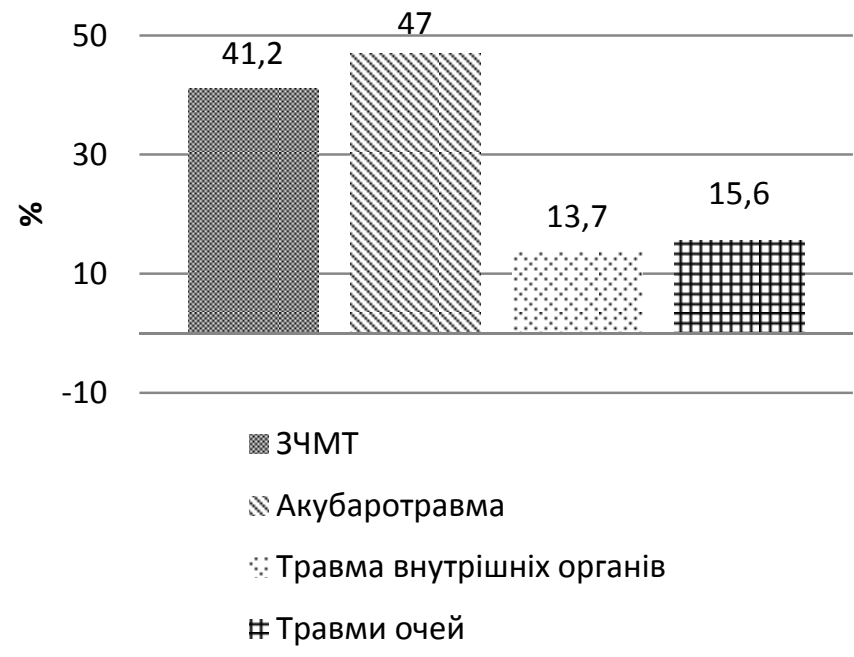

Рисунок.1. Структура ампутації за причиною.

Такі оцінювання необхідно проводити повторно на кожному етапі лікування, і вони мають входити до довгострокового ведення пацієнта. Ці дані дадуть змогу виявити пацієнтів із ризиком вчинення суїциду, великим депресивним розладом, ПТСР та гострою реакцією на стрес або розладом, спричиненим вживанням психоактивних речовин $[18,13]$.

Варто зазначити, що кожна 3 названих патологій мала негативний вплив на реабілітаційний процес.

Рисунок 2. Структура супутньої патології.

У пацієнтів 3 підтвердженим діагнозом акубаротравми мали місце порушення вестибулярної функції рівноваги. Частими наслідками ЗЧМТ та депресивних розладів були когнітивні порушення. За даними систематичних оглядів, когнітивна функція пов'язана 3 різними аспектами реабілітації після ампутації та з функціональним статусом пацієнта у майбутньому [3]. Існує взаємозв'язок між зниженою когнітивною функцією та неспроможністю особи після ампутації успішно застосовувати протез. Недостатність когнітивної функції також пов'язана із загальним зменшенням користування протезом, зменшенням мобільності, втратою незалежності та збільшенням частоти падінь [3]. Належне оцінювання когнітивної функції потребує багато часу від лікаря, однак воно забезпечує збір цінної інформації, яка допоможе встановити цілі та визначити прогноз. Таке оцінювання необхідно завжди поєднувати з регулярним повторним оцінюванням функції та цілей, щоб переконатися в тому, що пацієнт досягне їх повного функціонального потенціалу. 
Аналіз основних ускладнень, що виникали в процесі реабілітаційного лікування показав, що найчастіше у пацієнтів спостерігався фантомний біль - у 57\% (n=29). Біль у куксі відмічали 41,2\% (n=21), остеофіти - у 25,5\% (n=13), контрактури суглобів - в 11,8\% (n=6), гетеротопічні осифікати - в 4\% (n=1) (рис 3).

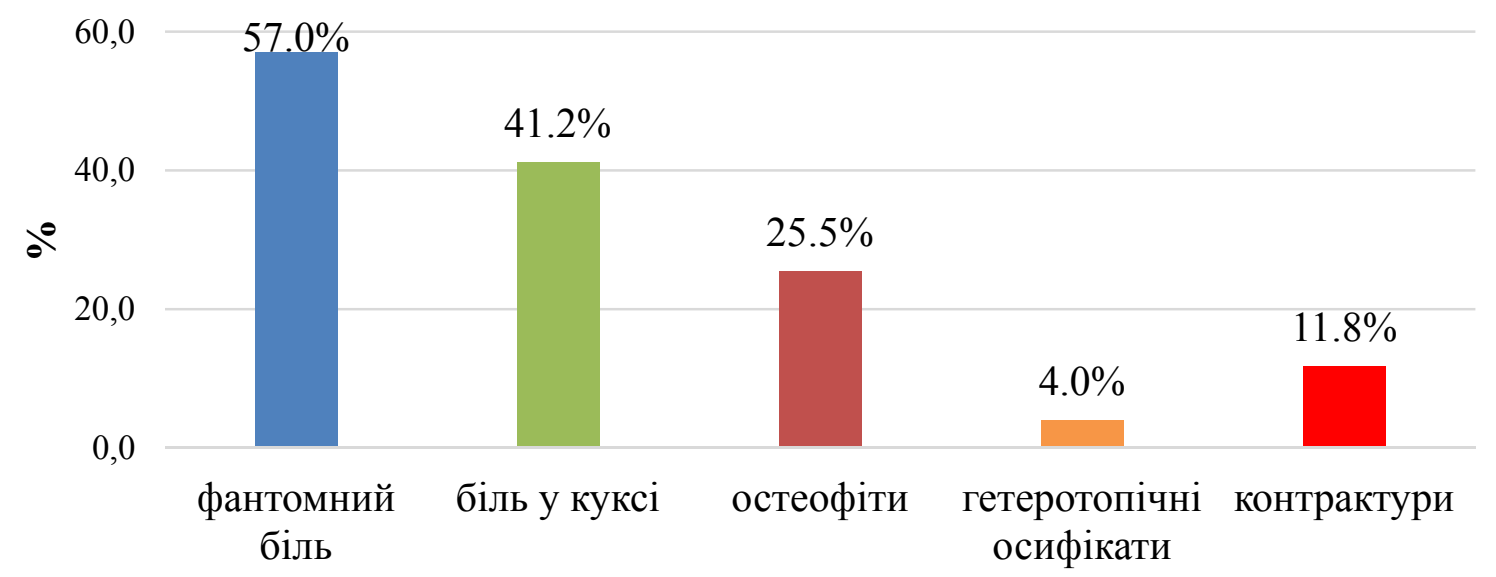

Рисунок 3. Основні ускладнення, що спостерігалися в процесі реабілітації.

Отже, проведений аналіз вказує на те, що існує багато факторів та особливостей, які повинні бути враховані в процесі реабілітації пацієнтів. Саме тому, алгоритм реабілітації військовослужбовців з ампутацією повинен відображати тактику оцінки стану пацієнта та план дій у разі виявлення проблеми з метою забезпечення ефективності реабілітаційних заходів та попередження ускладнень, враховувати потреби та цілі пацієнта, бути спрямованим на максимальне відновлення функціональної незалежності (рис. 4, 5).

На рис. 4 відображено алгоритм дій в періопераційному періоді реабілітації пацієнтів, яким планується проведення ампутації кінцівки та, яким уже виконана ампутація. Першим кроком $є$ створення МП команди, яка повинна провести всебічну оцінка стану пацієнта. Оцінка включає: стан кукси (розміри, форма, обсяг рухів, стан шкірних покривів, тощо), наявність больового синдрому, рівня мобільності, наявність супутніх травм та захворювань. Згідно стандартів надання медичної допомоги ветеранам з ампутацією Збройних Сил США, оцінка больового синдрому проводиться за візуальною аналоговою шкалою болю (ВАШ) [24]. Оцінку рівня мобільності проводять за розрахунком Прогностичного фактору рухової активності ампутанта без протезу (Amputee Mobility Predictor without prosthesis, AMPnoPRO), а на етапі протезування - Прогностичний фактор рухової активності ампутанта з протезом (Amputee Mobility Predictor with prosthesis, AMPPRO). Він дає змогу отримати оцінку за ранговою шкалою та характеризується зручністю, надійністю та чутливістю $[6,10]$. Крім того, він має референсні значення, завдяки яким особа, що проводить оцінювання, може оцінювати показники пацієнта відносно інших пацієнтів з порівнюваним функціональним статусом та етіологією. Оцінка супутніх травм та захворювань має не менше значення. У разі діагностики супутньої патології необхідним $є$ залучення відповідних спеціалістів та корекція відповідної проблеми.

Особлива увага приділяється психологічному стану пацієнта, сімейно-побутовому статусу. Періодичні оцінювання психічного статусу необхідно проводити повторно на кожному етапі лікування. Після всебічної оцінки стану пацієнта та виявлення проблем проводиться розробка ІПР, мета якої досягнути максимальної функціональної незалежності та цілей пацієнта. Цілі ІПР повинні бути реалістичними та орієнтовані на певні терміни, коректуватися в процесі реабілітації. У разі готовності пацієнта до комплексної реабілітації розпочинається підготовка до протезування (рис. 5) . Як правило, вона здійснюється у спеціалізованих закладах чи відділеннях. Після переведення пацієнта МПК повторно здійснює всебічний огляд пацієнта (загальний стан, стан кукси, супутня патологія, визначення рівня мобільності, тощо). В разі загоєння післяопераційної рани та формування рубця, проводиться менеджмент рубця; компресійна терапія та контроль об`єму кукси, навчання пацієнта правилам догляду за куксою та еластичного бинтування; фізична терапія із застосуванням вправ відкритого та закритого 
ланцюга та вправ зі збільшенням опору для покращення ходи, рухової функції, сили, балансу, функціонального стану серцево-судинної системи та показників щоденної діяльності з метою досягнення максимальних показників функціонального статусу; лікування супутньої патології; менеджмент больового синдрому; психотерапія. Після цього за потреби повторно проводиться корекція ІПР.

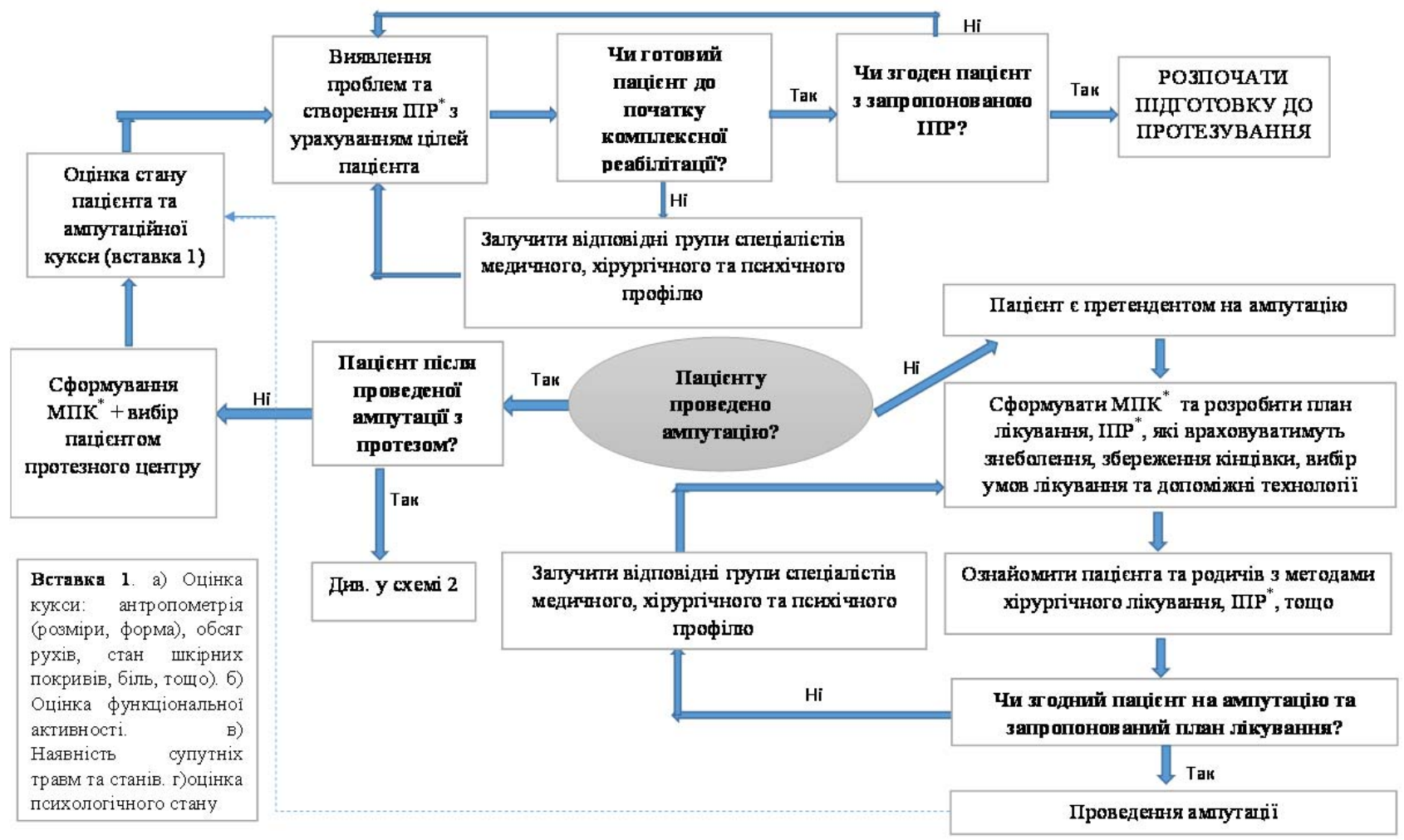

•МПК - мультнрофесійна команда (реабілітөлог, травматолог, протезнст, фі знчннй терапевт, пснхалог).

Рисунок 4. Алгоритм ведення пацієнта з ампутацією в періопераційному періоді.

Коли пацієнт готовий до протезування, розпочинається період протезування та навчання ходьби на протезі: спочатку - на тренувальному, далі - на первинному. Налаштування протеза зазвичай починається після формування рубця. Відповідно до функціонального класу, пацієнтам рекомендуються відповідні функціональні класи засобів для пересування. Пацієнтам з функціональним класом К«0» не рекомендовано використовувати протези для ходіння або пересування. Пацієнтам 3 функціональним класом К«1» рекомендується використовувати протези, які відповідають функціональним цілям обмеженого чи необмеженого пересування вдома. Пацієнтам з функціональним класом К«2» рекомендується використовувати протези, які відповідають функціональним цілям обмеженого пересування поза межами власного помешкання. У разі функціонального класу К«3» рекомендується використовувати протези особам, які пересуваються поза межами власного помешкання, можуть долати більшість перешкод середовища і можуть мати професійну, терапевтичну або тренувальну діяльність. Пацієнтам з функціональним класом К«4» рекомендується використовувати протези 3 найвищим рівнем функціональності, спортивні.

Перед початком освоєння протезу пацієнт повинен пройти інструктаж щодо безпечного падіння та піднімання, інструктаж зі щоденного огляду кукси на предмет надлишкового тиску на тканини, основ гігієни кукси і протеза. Навчання ходьби потрібно починати з участю допоміжних засобів. Після опанування навичок ходьби по рівній поверхні рекомендовано розпочати тренування на сходах, нерівностях, вгору/вниз схилами. Тренування 3 відпрацюванням ходи на протезі має охоплювати різні аспекти, пов'язані з середовищем помешкання, роботи та/або відпочинку пацієнта. Аналіз рівня мобільності та функціонального стану проводиться постійно. 
У разі, якщо пацієнт опанував ходьбу, розміри кукси стабілізувалися -проводиться заміна його на первинний.

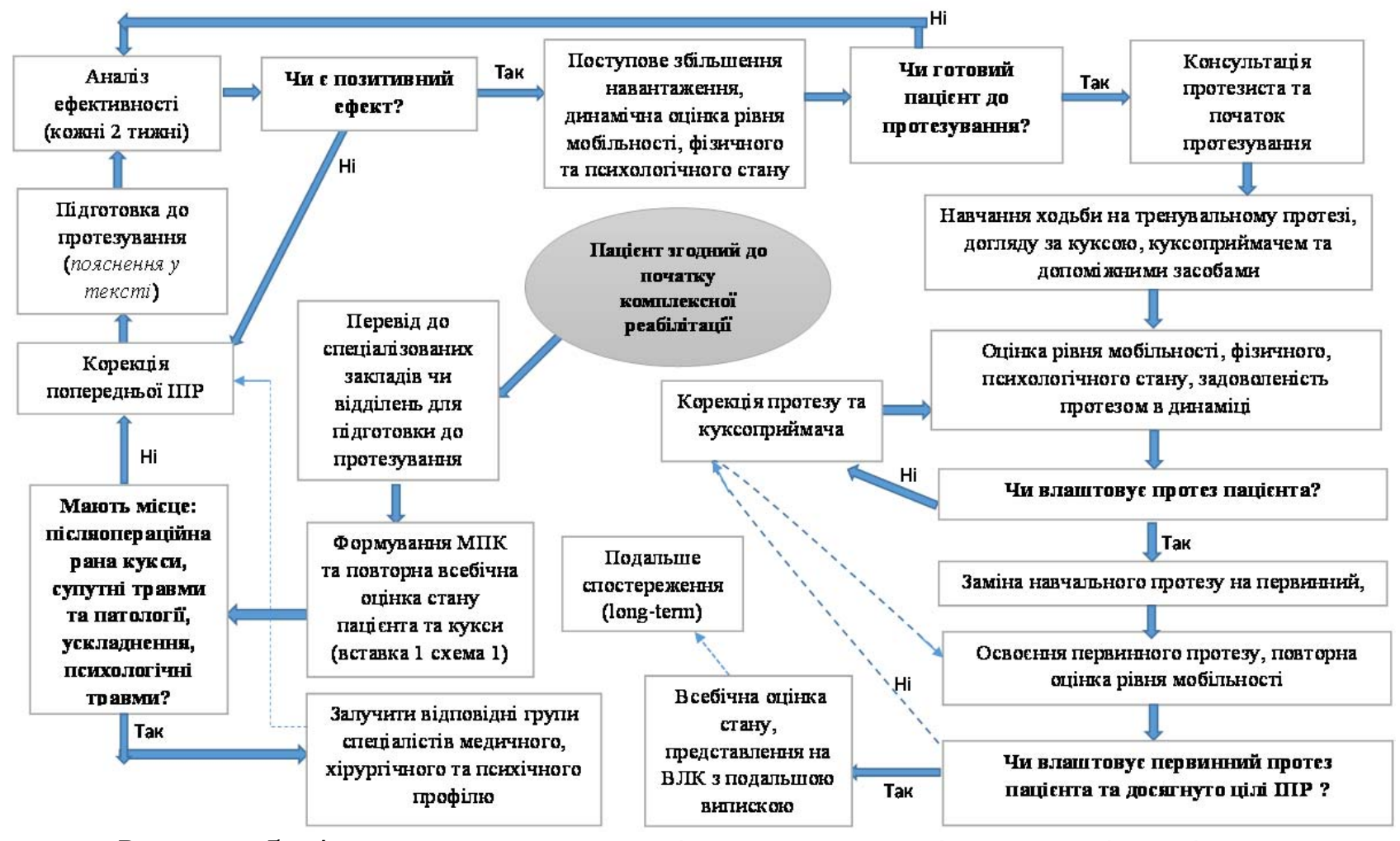

Рисунок 5. Алгоритм ведення пацієнта 3 ампутацією в період підготовки до протезування та протезування.

Виписка зі стаціонару відбувається у разі, якщо пацієнт отримав первинний протез, який його повністю задовольняє, досягнуті цілі реабілітації та максимально можлива функціональна незалежність

Пожиттєве лікування передбачає контроль пацієнта на предмет психосоціальної адаптації, патологій шкіри кукси, болю, скелетно-м'язових порушень, серцево-судинних захворювань, інших хронічних захворювань, здоров'я контралатеральної кінцівки та забезпечення використання відповідного взуття для контралатеральної кінцівки.

\section{Висновки.}

1. Аналіз основних ускладнень, що виникали в процесі реабілітаційного лікування пацієнтів з ампутаціями показав, що найчастіше у них спостерігався фантомний біль - у 57\%, біль у куксі відмічали 41,2\%, остеофіти - у 25,5\%, контрактури суглобів- в 11,8\%, гетеротопічні осифікати - в 4\%. Серед супутньої патології найчастіше виявлялися акубаротравма - 47\%, закрита черепно-мозкова травма - 42,2\%, травми внутрішніх органів - 13,7\%, травматичні ураження очей $-15,6 \%$.

2. Розроблено алгоритм реабілітації військовослужбовців з ампутацією, який враховує характер сучасної травми, часту асоціацію ампутації з іншими м`язово-скелетними травмами, травмами внутрішніх органів, психологічними розладами, соматичною патологією, особливості ускладнень в процесі лікування та реабілітації та досвід передових країн НАТО.

3. Запропоновано комплексне лікування 3 диференційованим індивідуальним підходом та застосуванням сучасних технологій, ранній початок реабілітації на основі МП підходу та згідно ІПР.

Перспективи подальших досліджень. Подальші дослідження можуть бути спрямовані на вивчення особливостей реабілітації 3 наявністю післяопераційних ускладнень, їх менеджмент та протезування. 


\title{
References
}

\section{Література}

1. Andrews J, Guyatt G, Oxman AD, et al. GRADE guidelines: 14. Going from evidence to recommendations: The significance and presentation of recommendations. J Clin Epidemiol. Jul 2013;66(7):719-725.

2. Brunelli S, Morone G, Iosa M, et al. Efficacy of progressive muscle relaxation, mental imagery, and phantom exercise training on phantom limb: A randomized controlled trial. Arch Phys Med Rehabil. Feb 2015;96(2):181-187.

3. Coffey L, O'Keeffe F, Gallagher P, Desmond D, Lombard-Vance R. Cognitive functioning in persons with lower limb amputations: A review. Disabil Rehabil. 2012;34(23):1950-1964.

4. $\quad$ Critchton N. Visual analogue scale (vas). J Clin Nurs. 2001;10.5:706

5. $\quad$ Ertl JP, Pritchett JW, Ertl W, Brackett WJ. Lower-extremity amputations. Medscape. Apr 042016.

6. Gailey RS, Roach KE, Applegate EB, et al. The Amputee Mobility Predictor: An instrument to assess determinants of the lower-limb amputee's ability to ambulate. Arch Phys Med Rehabil. May 2002;83(5):613-627.

7. Hasanadka R, McLafferty RB, Moore CJ, Hood DB, Ramsey DE, Hodgson KJ. Predictors of wound complications following major amputation for critical limb ischemia. J Vasc Surg. Nov 2011;54(5):1374-1382.

8. Ministry of Defence of USA. Amputation statistics 1 April2013-31 March 2018. Available from: https://assets.publishing.service.gov.uk/government/uploads/system/uploads/attachment dat a/file/728224/20180612 Amputation_Statistic 0 v2.pdf. Accessed: July 26, 2018.

9. Ministry of Defence of Ukraine. Available from: http://www.mil.gov.ua/news/2016/07/07/nasogodni-vzhe-protezovano-92-vidsotki-zahisnikiv-batkivshhini-z-nih-90-vidsotkiv-na-proteznih-pidpriemstvahukraini--/. Accessed: July 7, 2016.

10. Resnik L, Borgia M. Reliability of outcome measures for people with lower-limb amputations: Distinguishing true change from statistical error. Phys Ther. Apr 2011;91(4):555-565.

11. Sinha R, van den Heuvel WJ, Arokiasamy P. Adjustments to amputation and an artificial limb in lower limb amputees. Prosthet Orthot Int. Apr 2014;38(2):115-121.

12. Tsema IE, Bespalenko A. Analysis of limb amputations during armed conflict at the East of Ukraine. Norwegian Journal of Development of the International Science. 2016;(1):79-80.

13. Tuncay T, Musabak I. Problem-focused coping strategies predict posttraumatic growth in Veterans with lower-limb amputations. Journal of Social Service Research. 2015/08/08 2015;41(4):466-483.

14. U.S. Department of Veteran Affairs, Department of Defense. Rehabilitation of Lower Limb Amputation. Available from: https://www.healthquality.va.gov/guidelines/Rehab/amp/ Accessed: September, 2017

15. VA Amputee Data Repository. VHA Support Service Center. January 2017.

16. Varma P, Stineman MG, Dillingham TR. Epidemiology of limb loss. Phys Med Rehabil Clin N Am. Feb 2014;25(1):1-8.

17. Webster JB, Poorman CE, Cifu DX. Guest editorial: Department of Veterans Affairs Amputations System of Care: 5 years of accomplishments and outcomes. J Rehabil Res Dev. 2014;51(4):vii-xvi.

18. Wegener ST, Mackenzie EJ, Ephraim P, Ehde D, Williams R. Self-management improves outcomes in persons with limb loss. Arch Phys Med Rehabil. Mar 2009;90(3):373-380.

\section{АЛГОРИТМ РЕАБИЛИТАЦИИ ВОЕННОСЛУЖАЩИХ С АМПУТАЦИЯМИ КОНЕЧНОСТЕЙ НА ОСНОВАНИИ МУЛЬТИПРОФЕСИОНАЛЬНОГО И ИНДИВИДУАЛЬНОГО ПОДХОДА}

\author{
А.А. Беспаленко ${ }^{1}$, О.И. Щеглюк ${ }^{1}$, А.Ю. Ких ${ }^{1}$, О.А. Бурьянов르, А.Н. Волянский ${ }^{1}$, \\ В.В. Корченок ${ }^{1}$, М.О. Михайловская ${ }^{1}$
}

\begin{abstract}
${ }^{1}$ Военно-медицинский клинический реабилитационный центр, г. Ирпень
${ }^{2}$ Национальний медицинский университет имени А.А. Богомольца, г. Киев
\end{abstract}

По данным литературы, среди участников АТО, ООС преобладают ранения конечностей - 62,5\%. Частота ампутации сохраняется относительно высокой, часто сочетается с другими травмами мышечно-скелетной системы и требует индивидуального и мультипрофесионального (МП) подхода.

Цель исследования: провести анализ структуры ампутаций у участников АTO OОС; создать алгоритм реабилитации военнослужащих с ампутацией, учитывая индивидуальный и МП подход.

Материалы и методы. Проведен анализ результатов лечения 51 пациента с ампутацией из числа участников $\mathrm{ATO}, \mathrm{OOC,} \mathrm{которые} \mathrm{были} \mathrm{госпитализированы} \mathrm{в} \mathrm{отделение} \mathrm{реабилитации} \mathrm{пациентов} \mathrm{с}$ ампутированными конечностями Военно-медицинского клинического центра профессиональной патологии ВСУ в период с 26.12.2016 по 01.08.2019. Средний возраст на момент ранения составлял - 33 года (от 18 до 54). Распределение по полу: мужчины - 98,1\% ( $n=50)$ женщины - 1,9\% $(n=1)$. 
Результаты исследования. Отсутствие одной конечности вследствие ампутации наблюдалась в 84,3\% ( $n=43)$, двойная ампутация - в 13,7\% ( $n=7)$, тройная - в 2,0\% (n = 1). Основной причиной ампутации были минно-взрывные ранения - 78,4\% ( $n=40)$. Чаще всего ампутация конечностей сочеталась с акубаротравмою - 47\% ( $n=24)$ и закрытой черепно-мозговой травмой - 41,2\% ( $n=21)$. Частыми сопутствующими расстройствами были нарушения адаптации и депрессивные расстройства 56,8\% ( $n=29)$. В 31\% ( $n=16)$ ампутация сочеталась с переломами трубчатых костей других конечностей. Все эти обстоятельства существенно влияли на ход реабилитации. Учитывая вышеуказанные обстоятельства, нами было предложено алгоритм реабилитации пациентов $c$ травматической ампутацией в периоперационном периоде, периоде подготовки к протезированию, протезирования и отдаленном периоде в соответствии с индивидуальной программой реабилитации (ИПР).

Выводы. Учитывая особенности современной травмы, а именно частую ассоциацию ампутации с другими мышечно-скелетными травмами, травмами внутренних органов, психологическими расстройствами, алгоритм ведения пациентов с ампутацией должен включать: комплексное лечение с дифференцированным индивидуальным подходом по применению современных технологий, раннее начало реабилитации и МП подход.

Ключевые слова: ампутация, мультипрофесиональний подход, протезирование, реабилитация.

\title{
ALGORITHM FOR REHABILITATION OF COMBAT-RELATED PATIENTS WITH LIMB AMPUTATIONS BASED ON MULTIPROFESSIONAL AND INDIVIDUAL APPROACH
}

\author{
A.A. Bespalenko¹, 0.I. Shchehliuk¹, A.Y. Kikh¹, O.A. Buryanov², O.M. Volyansky', \\ V.V. Korchenok ${ }^{1}$, M.O. Myhailovska1 \\ ${ }^{1}$ Military Medical Clinical Treatment \& Rehabilitation Center, Irpin \\ ${ }^{2}$ National Medical University named after 0.O. Bohomolets, Kyiv
}

Introduction. According to the literature, limb injuries predominate (65\%). among the participants of the Anti-terrorist Operation (AO), Joint Forces Operation (JFO) The amputation rate is relatively high, often combined with other musculoskeletal injuries, and requires an individual and multi-professional (MP) approach.

Purpose of the study: to analyze the structure of amputations in participants of $A O$ and JFO; to create an algorithm for the rehabilitation of military personal with amputations, taking into account the individual and MP approach.

Materials and methods. The analysis of the results of treatment of 51 patients with amputation from the participants of $A O, J F O$, who were hospitalized in the department of rehabilitation of patients with amputated extremities of the Military Medical Clinical Center of Occupational Pathology of the Armed Forces in the period from 26.12.2016 to 01.08.2019. The average age at the time of injury was 33 years (from 18 to 54). Distribution by gender: men - 98.1\% $(n=50)$, women - 1.9\% $(n=1)$.

Results. The absence of one limb due to amputation was observed in $84.3 \%(n=43)$, double amputation $13.7 \%(n=7)$, triple - in $2.0 \%(n=1)$. The main cause of the amputation was a mine-explosion injury $-78.4 \%(n=$ 40). Most often, limb amputation was combined with acubarotrauma $-47 \%(n=24)$ and closed traumatic brain injury - $41.2 \%(n=21)$. Adaptation disorders and depressive disorders were common concomitant disorders (56.8\% $(n=29))$. In 31\% ( $n=16)$ amputation was combined with fractures of tubular bones of other extremities.

These circumstances significantly influenced the course of rehabilitation. Given the above circumstances, we have proposed an algorithm for the rehabilitation of patients with traumatic amputation in the postoperative period, the period of preparation for prosthetics, prosthetics and the remote period in accordance with the individual rehabilitation program (IRP).

Conclusion. Given the specific of modern trauma (first of all the frequent association of amputation with other musculoskeletal injuries, injuries of the internal organs, psychological disorders) the algorithm for managing patients with amputation should include: complex treatment with differentiated individual approach, using modern technologies MP approach and according to IRP.

Keywords: amputation, multiprofessional approach, prosthetics, rehabilitation

Конфлікт інтересів: відсутній.

Conflicts of interest: authors have no conflict of interest to declare.

$A$ - концепція та дизайн дослідження; $B$ - збір даних; $C$ - аналіз та інтерпретація даних; $D$ написання статті; $E$ - редагування статті; F - остаточне затвердження статті 


\section{Відомості про авторів.}

Беспаленко А. А., A, B, C, D, E, підполковник медичної служби, магістр медицини, старший ординатор відділення травматології Військово-медичного клінічного лікувально-реабілітаційного центру, м. Iрпінь; e-mail: dr.bespalenko@ukr.net;

Щеглюк О. I., ${ }^{B,} \boldsymbol{C}, \boldsymbol{D}$ магістр медицини, старший ординатор відділення реабілітації пацієнтів 3 ампутованими кінцівками Військово-медичного клінічного лікувально-реабілітаційного центру, м. Ірпінь;

Kix А. Ю., С ,D, Е полковник медичної служби, канд. мед. наук, начальник Військово-медичного клінічного лікувально-реабілтаційного центру, м. Ірпінь;

Бур'янов О. А., $\boldsymbol{C ,} \boldsymbol{D}, \boldsymbol{E}, \boldsymbol{F}$ д. мед. наук, проф., завідувач кафедри травматології та ортопедії НМУ ім. О.О. Богомольця, м. Київ;

Волянський О. М., $\boldsymbol{B}, \boldsymbol{C}, \boldsymbol{E}$ полковник медичної служби, канд. мед. наук, начальник клініки реабілітації, професійної патології та нетрадиційних методівлікування Військово-медичного клінічного лікувально-реабілтаційного центру, м. Ірпінь;

Корченок В. В., ${ }^{B, C}, \boldsymbol{E}$ полковник медичної служби, начальник відділення реабілітації пацієнтів 3 ампутованими кінцівками Військово-медичного клінічного лікувально-реабілітаційного центру, м. Ірпінь;

Михайловська М.М., ${ }^{\boldsymbol{B}, \boldsymbol{E}}$ фізичний терапевт відділення реабілітації пацієнтів з ампутованими кінцівками Військово-медичного клінічного лікувально-реабілітаційного центру, м. Ірпінь;

Сведения об авторах:

Беспаленко A.A., A, B, C, D, E, подполковник медицинской службы, магистр медицины, старший ординатор отделения травматологии Военно-медицинского клинического лечебно-реабилитационного центра, г. Ирпень; e-mail: dr.bespalenko@ukr.net;

Щеглюк А. И., B, C, D магистр медицины, старший ординатор отделения реабилитации пациентов с ампутированными конечностями Военно-медицинского клинического лечебно-реабилитационного центра, г. Ирпень;

Ких А. Ю., C,D,E полковник медицинской службы, канд. мед. наук, начальник Военно-медицинского клинического лечебно-реабилтацийного центра, г. Ирпень;

Бурьянов А. А., C, D, E, F д. мед. наук, проф., заведующий кафедрой травматологии и ортопедии НМУ им. А.А. Богомольца, г. Киев;

Волянский А. Н., в, С, Е полковник медицинской службы, канд. мед. наук, начальник клиники реабилитации, профессиональной патологии и нетрадиционных методов лечения Военно-медицинского клинического лечебно-реабилтацийного центра, г. Ирпень;

Корченок В. В., в, С, Е полковник медицинской службы, начальник отделения реабилитации пациентов с ампутированными конечностями Военно-медицинского клинического лечебнореабилитационного центра, г. Ирпень;

Михайловская Н. М., $\boldsymbol{B}, \boldsymbol{E}$ физический терапевт отделения реабилитации пациентов с ампутированными конечностями Военно-медицинского клинического лечебно-реабилитационного центра, г. Ирпень;

Information about authors:

Bespalenko A. A., $\boldsymbol{A}, \boldsymbol{B}, \boldsymbol{C}, \boldsymbol{D}, \boldsymbol{E}, \mathrm{LtC}$ MS, master of medicine, senior resident of the traumatology department of the Military Medical Clinical treatment and Rehabilitation Center, Irpin; e-mail: dr.bespalenko@ukr.net;

Shchehliuk 0. I., B, c, D Master of Medicine, Senior Resident of the Department of Rehabilitation of Patients with Amputated Limbs of the Military Medical Clinical treatment \& Rehabilitation Center, Irpin;

Kikh A. Y., c, D, E Col. MS, MD, PhD, Head of the Military Medical Clinical Treatment \& Rehabilitation Center, Irpin

Buryanov 0. A., C, D, E, F MD Dsc., Prof., Head of the Department of Traumatology and Orthopedics 0.O.Bogomolets NMU, Kyiv;

Volyansky O. M., B, C, E Col. MS, MD, PhD, Head of the Clinic of Rehabilitation, Occupational Pathology and Non-Traditional Methods of Treatment of the Military Medical Clinical Treatment \& Rehabilitation Center, Irpin;

Korchenok V. V., B, c, E Col. MS, Head of the Department of Rehabilitation of Patients with Amputated Limbs of the Military Medical Clinical Treatment \& Rehabilitation Center, Irpin;

Myhailovska M. M., ${ }^{B, E}$ physical therapist of the Department of Rehabilitation of Patients with Amputated Limbs of the Military Medical Clinical Treatment \& Rehabilitation Center, Irpin; 